\title{
DDX41 Gene
}

National Cancer Institute

\section{Source}

National Cancer Institute. DDX41 Gene. NCI Thesaurus. Code C151913.

This gene may play a role in RNA splicing and tumor suppression. 